\title{
Online Streaming and Self-Dependence among the Niqabi Students in University
}

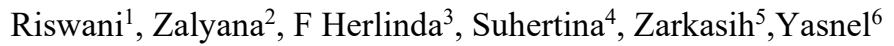 \\ Fakultas Tarbiyah dan Keguruan, Universitas Islam Negeri Sultan Syarif Kasim Riau 1,2,3,4,5,6 \\ \{riswani@uin-suska.ac.id ${ }^{1}$ \}
}

\begin{abstract}
This paper seeks to examine the dependence of female students on streaming as a means of religious learning related to the use of niqab as clothing that covers the Muslim woman's nakedness and the psychological impacts resulting from such dependence. In its discussion, the authors used Rokeach and Defleur's Dependency Theory. This research is qualitative using a phenomenology method. The informants were seven female students who are wearing niqab within the criteria determined by the researchers. In gaining the data, the researchers interviewed and observed seven niqabi students. The results showed that religious learning through streaming is more interesting and efficient compared with other social media. It also revealed that excessive intensity and time to study niqab through online streaming on social media have caused a dependent effect on social media. The dependent effect on social media was in the form of low self-control among the students. This is following Rokeach and DeFleur's Dependency Theorythat individuals tend to be dependent on mass media that provide more rather than less information needed. Campus, as one of the parties that has the responsibility to understand the religious behaviors of the students, should guide them students towards religious learning.
\end{abstract}

Keywords: Niqab, Social Media, Religious Learning

\section{Introduction}

One of the recent popular activities among teenagers on social media is streaming, which is accessing video or audio through the internet without downloading [1]. Two forms of streaming can be accessed. The first is streaming prerecords, which is a video that has been recorded, stored, and then broadcasted. The second is live streaming, which is recording audio or video directly and broadcasting it live through the desired application, such as Live TV broadcasts and Creative Radio [2]. Some people disagree with the presence of streaming on social media because it may broadcast easily harmful content, but still, it is a favorite among the fans. Ericsson noted an increase in the frequency of watching videos in streaming and the time spent streaming among teenagers each year. In 2011 only about 7\%, teenagers aged 1619 years watched videos via YouTube. The time they use was about 3 hours per day. Four years later, it increased to $20 \%$, and the time used tripled [3]. The results of interviews 
conducted by the Consumer Lab Trends in 4000 millennials in 24 countries in 2016 showed that native streaming behavior was a widespread behavior among millennials [4].

It is undeniable that social media facilities on the internet, such as Facebook, Line, WhatsApp, Instagram, Twitter, YouTube, and streaming, have taken a significant role in human life today. It has created essential power in social interaction between individuals, which then unconsciously has a psychological impact on its users. It has also caused changes in the structure of human life, be it socially, culturally, economically, politically, and educationally. In the context of Islamic $d a$ 'wah (teaching and socializing about Islam), it creates opportunities for anyone to convey teachings that are believed to be truthful and liked. This makes the passion for using the internet to study religious knowledge shows an increasing trend [5]. This phenomenon can be seen from the emergence of clerics who utilize social media in conveying religious knowledge [6]. In general, they have hundreds of followers and even thousands. This phenomenon has created the term of cyber religion [7].

Clerics discusses various religious issues through streaming in their respective styles. One of them is the issue of using niqab for Muslim women. The niqab is the syar' $i$ term for a veil, which is a kind of cloth used to cover faces. Nisa mentioned that the veil is a cloth that covers the face of the wearer [8]. The law on the use of the niqab as clothing that covers the aurat (body parts of Muslim women that must be covered) has been debated among scholars. As a result, there are pros and cons related to the use of niqab, and the negative stigma may reinforce these pros and cons against niqab (niqabi) users, such as the link between niqabi and the issue of terrorism. Even, the ban on the use of niqab among students in several Islamic universities has been a heated controversy in Indonesia [9].

There are still pros and cons to the wearing of the niqab. However, the number of female students who decide to use the niqab at the Sultan Syarif Kasim Riau State Islamic University continues to grow. At first, there were only a few niqabi in individual faculties, now it is almost to one hundred, spreading across all faculties and it is estimated that the number will increase in the new school year. All who decide to wear the niqab are students who are active in religious streaming. Early indications also show that female students decided to wear the niqab based solely on the guidance of the clerics, which is accessible through streaming. The actions of the female students showed as if streaming was the only divine source and confirmed that the religious authority has been shifted[10].

From a revivalism viewpoint, the phenomenon of an increasing number of niqabi among female students as a result of cyber religion is a positive thing. However, from the Dependency Theory perspective, this can hurt the users who are dependent on technology such as social media [11]. Technology encourages its users towards technology culture, in which the technology is controlling life [12].

The researchers on social media and niqab have been written by Nisa entitled "The Internet Subculture of Indonesian Face-Veiled Women." This article discusses how niqabi from Salafi groups create and maintain subculture through mailing lists [8]. Piela writes, "Online Islamic Spaces as Communities of Practice for Muslim Women Converts Who Wear the Niqab." Using the concept of the Rambo's Conversion Model and the concept of the Live and Wenger Community, Piele analyzes the niqabi online discussions on why they are wearing the niqab despite the challenges coming from most Muslims [13]. Furthermore, Piela also wrote, "How do Muslim Women Who Wear The Niqab Interact with Others Online? A Case Study of a Profile on a Photo-Sharing Website". Piela's research used a case study method in observing how the niqabi actualize themselves through their photos and conversations in online media [14]. Afifah focused her research on the "Syar'i discourse on social media by taking the approach analysis of Ernesto Laclau and Chantal Mouffe" [15]. 
Fathonah wrote the "Syar'i Female Headgear Trend and the Veil Polemic; Observing the Stretching of Indonesian Contemporary Islam." In this study, Fathonah described the phenomenon of the veil and niqab in Indonesia, and she concluded that the veil and niqab are multifocal and become a cultural symbol between one group and another [16]

This article aims to reveal the niqabi's dependence on streaming as a means of learning Islamic values related to the use of the niqab for covering the Muslim woman's nakedness and its psychological impact on the niqabi's dependency. In the discussion, the authors follow Rokeach and Defleur's Dependency Theory.

\section{Method}

This research is qualitative, using the phenomenology approach conducted at Sultan Syarif Kasim Riau State Islamic University for approximately six months. The informants in this study were all female students who are wearing niqab, amounting to 96 people. They were scattered throughout the Faculties in UIN Suska Riau. Determination of the informants was done by purposive sampling technique. This technique determines the taking of participants based on criteria that have been determined by the researchers in line with the needs and objectives of the study [17]. The informant criteria, among others, include 1) students who have been using niqab for at least one year; 2) minimum niqab is used when they are in campus; and 3) actively streaming or making streaming as a divine source related to the use of $n i q a b$ in addition to other sources. Based on these requirements, seven niqabi people were selected as research informants.

There are two techniques used in collecting data, namely observation, and interviews. Nonparticipant observation is carried out when the interview process is taking place. The aim is to find out non-verbal behaviors and expressions of research informants in order to help the researchers understand their experiences and to maintain effective interviews. Interviews were conducted semi-structured with guidelines for in-depth interviews in order to obtain comprehensive data related to streaming dependency and niqab.

The data processing steps start with verbatim and interview data transcription. The overview is done by reading the transcription repeatedly without any prejudice in order to understand the underlying meaning of the phenomenon as a whole. The next step was to compile a description of individual phenomena (DIP) by removing the repetition of statements in transcription and then separating units of meaning (words or phrases in transcription) that contain unique and coherent meanings that differ from other meaning units.

\section{Result and Discussion.}

This section discusses research findings related to how vital social media streaming is for the niqabi as a source of diversity where then they commit and decide to use the niqab. The level of need for the use of the media will indicate their levels of dependence on the media as a source of their searches for religious information.

Several theories explored individual dependence on mass media. Mass media, in this case, refers to social media that is limited to video and TV streaming. One of them is the Dependency Theory developed by Rokeach and DeFleur. The theory "identifies how people become dependent on the media to meet their needs" [18]. Through this theory, Rokeach and DeFleur suggested two things to determine an individual's dependence on social media. First, the individuals need more information available in the media so that they tend to choose the 
media than provides more than less information that they need. Second, the percentage of dependency is also determined by social stability at the time [19].

This discussion is only focused on the first thing from the Theory of Dependency, which is the provision of more information that is needed by the individuals. The millennial generation is efficient and is lack of interests in conventional reading [20] Millennials tend to use social media to learn religious values [21]. The emergence of the learning behaviors of religious values or via the internet and the interests in instant things seems has benefited the clerics to convey religious knowledge both in video streaming and live TV, including in the issues of niqab use among Muslim women. It is quite easy to find on YouTube, Facebook, and another media the discussion about niqab, which is available on streaming or live by the clerics from various religious preachers, such as Abdul Shomad, Syafiq Reza Basalamah, Felix Siauw, Hanan Attaki, the late Arifin Ilham and many others. Many TV channels focus on religious propaganda invite clerics to give religious advice through live TV streaming.

According to the niqabi, studying religious values through streaming facilities is more efficient and more practical, time-saving, and attractive compared to other facilities available on social media. In their opinions, by streaming, they no longer need a TV, which has more expensive costs than a smartphone. They do not need to read or go to the mosque or join a halaqah group(a group of learning religious knowledge) in their busy work on college assignments and other campus activities. Learning religious activities can be done in a relaxed way, such as lying in bed. It is also very flexible in the sense that they do not need to see the manhaj and place to learn because they know clearly who are the teachers. The material delivered by the clerics were not edited, following the original. Besides that, they do not feel ashamed to engage in interactive dialogues directly with the clerics if there are things they do not understand from the materials presented because their faces are invisible. Another essential answer is that by streaming, they can get knowledge from favorite clerics they admire anywhere and anytime. More importantly, according to them, these clerics are very qualified Islamic scholars in their field and there is no reason to have a doubt on them.

Another benefit that the niqab has in their use of social media streaming facilities in studying Islam, especially the use of niqab, is that their accesses through streaming can strengthen their belief in using the niqab both inside and outside campus because they get the same understanding from a variety of clerics who have in-depth knowledge about Islam. For them, niqab is not only a cover for the genitals or fashions but furthermore, it is a manifestation of the Muslim faith. They feel unaffected by ridicule or restrictions on the use of $n i q a b$ on campus. When they are asked what to do if there is a ban on the use of the niqab on campus,some of the niqabis answered that if the rule is absolute, they will follow and pray that God will give guidance to the campus leadership. At the very least, we only open when we are in class. However, some have a great and unwavering faith because of which they are ready to die or leave campus if there is a ban on using it. Strangely, thoseniqabisfind it imperative to open the niqab when returning home because theydo not want to conflict with their mother, who was less supportive of the niqabthey were wearing.

Oktisia concluded in her research that the individual's need for information and the availability of facilities to meet these desires led to the emergence of media dependence [22]. Thus, it can be inferred that the availability of religious knowledge facilities through streaming or live streaming will be following students' desires on streaming or live streaming.

Gómez, Rial, Braña, Golpe, \& Varela, 2017; Kuss \& Griffiths, 2014; Salicetia, 2015 stated that individuals who depend on the media could be seen from the frequency and duration of the use [23]. The time limit online is 4 hours, 17 minutes a day [24]. The niqabis interviewed said that before using the niqab, they were active on several other social media every day. 
After wearing the niqab, they remained active; only more time was given to streaming materials about the use of the niqab from their favorite clerics. This activity was carried out until they were convinced that the niqab was the best dress for Muslim women and decided to use it even though they knew that the law of using niqab is recommended (sunnah), not mandatory.

Every niqabi has a different experience regarding how long they need to stream before and after using the niqab. Some niqabis do streaming in a matter of months, but some only stream directly using the niqab because they have previously joined the study group. After using the niqab, streaming is still done, but the frequency depends on the availability of money or the availability of free Wi-Fi. From the aspect of the purpose of streaming, there is a change before and after using the niqab. Before using the niqab, the purpose of streaming is to convince themselves that the niqab is the best clothing for Muslim women. After using the $n i q a b$, the purpose of streaming is to maintain the belief that the niqab is the best clothing for Muslim women. Also, streaming activities are not only for niqab materials but also for other religious issues. The niqabi responses also showed that they feel less satisfied if they do not stream related to other religious materials.

Almost all respondents interviewed mentioned that they spent 2 or 3 hours per day or adjusted to the duration of the program they watched while they are studying religious materials they need or repeating streaming on the same material to strengthen their religious beliefs and behaviors. Even, niqabis may also spend 4 hours per day until finally deciding to use the niqab. For streaming, they can spend an average of 3 hours per day, if coupled with the use of other media such as Facebook, Instagram, WhatsApp, and others. The niqabis spend time on social media more than 4 hours a day.

Another aspect that niqabi must address is related to streaming funds. The average niqabi spends Rp. 300.000 per month and can even reach Rp. 400,000. In general, they have budgeted monthly credit funds from their parents' remittances, and if the money needs to exceed the allocated funds, then they will use pocket money, and some even use funds for college needs. It seems that budgeting credit funds for the niqabis have become an obligation because free wifi is minimal, especially streaming is generally done in boarding houses. For the niqabis, Allah will make it easier for people to do best so that funds will be naturally available.

Students are a vulnerable group that makes social media as something fundamental in their lives. This is because they are in a transition phase from late adolescence to adulthood so that psychological dynamics still occur [24]. In this phase, the process of forming self-identity is still in the form of trying to live independently and escape from the influence of parents. Also, their characters in managing the needs of life, interpersonal relationships, and cognitive, emotional development is still unstable [25]. In such unstable situations, on-line activities become the primary choice because these activities can expand their social networks [26]Unconsciously, they make online activities as the first choice for social support and interpersonal relationships. Even the fact will hurt their lives because it leads to behavioral dependency on these activities. They also do not realize that interacting well with anyone and in any social context requires testing and experience through direct contact with others.

Young, Freitag, and Weaver mentioned the symptoms of dependence on social media, including a preoccupation with social media, where the users always think about it while offline and use social media to overcome their problems [27]. Thesis by Young, Freitag, and Weaver is found also in the niqabis, as seen from their statements that studying religion through streaming is very exciting. Besides being practical, the tausiah (religious speaking) is conveyed by their favorite clerics so that they are bored seeing it repeatedly. They also stated 
that through streaming, the clerics were able to answer their anxiety and desire to use the niqab.

Among the psychological disorders arising from those who are dependent on social media include fear of anxiety, anxiety, boredom, confusion, and others [28]. Asih and Fauziah found dependence on social media has an influence on low self-control [29]. Self-control is the ability to regulate behavior or the ability to control behavior or refrain from temptation [30]. In the niqabi's case, the lack of self-control can be seen primarily from the statement of one niqabi who said she was ready to leave campus or die if their niqabis banned on campus, even though he knew that the law using the niqab was only sunnah (not mandatory). On the other hand, they are willing to open the niqab if they return home because they do not want a fight with parents who do not approve their uses of niqab.

\section{Conclusion}

Using streaming on social media as a means of religious learning related to the use of the $n i q a b$ can change students' understanding and religious behaviors until they decided to use niqab. Accordingly, streaming can fulfill their needs because it is more practical, efficient, and attractive compared to other facilities available on other social media. Another cause is the use of streaming as a media search, and the delivery of the information is a trend among people who use social media. There is a sense of pride among the students to study Islam through streaming. This is following Rokeach and DeFleur's Dependency Theory in which it is said that individuals tend to be dependent on the mass media that provide more information they need.

The use of video streaming as a media to learn religious knowledge for students has raised dependency behaviors because of excessiveness, intensity, and time. This dependence has psychological effects, including weak self-control. Campus as one of the parties that has the responsibility for students' understanding and religious behaviors should guide them to study religious knowledge. The aim is to prevent students from being addicted and to reduce the psychological impacts that they can suffer. Coaching can be done by an academic advisor and a university counseling center. For this reason, it is recommended that academic advisors should have the same understanding related to learning Islamic knowledge via streaming.

\section{References}

[1] de tekno, "Apa itu streaming dan hal yang perlu diketahui pada streaming video dan audio[What is streaming and what you need to know about video and audio streaming]," 2017.

[2] F Arsya Inzaghi, “Apa itu streaming?," 2018. .

[3] Kominfo, "Mengenal generasi milineal," in The Kominfo listed on its website, 2016.

[4] Kompas, "Penggunaan 'Smartphone' di Genggaman Generasi Millennial," 2018.

[5] Rahman. F, Matinya Sang Dai: Otominisasi Pesan-Pesan Keagamaan di Dunia Maya. Pemulang Tanggerang Selatan: Lembaga Studi Islam Progresif (LSIP), 2011.

[6] A. Amar, "Dinamika Komunkasi Islami di Media Online," J. Ilmu Komun., vol. 11, no. 1, pp. 44-48. 
[7] Hatta.M. Media Sosial, "Sumber Keberagamaan Alternatif Remaja (Fenomena Cyberreligion Siswa SMA Negeri 6 Depok Jawa Barat)," in Alternative Religious Sources of Youth (Cyberreligion Phenomenon Students of State Senior High School 6 Depok, West Java, Thesis, 2018.

[8] Nisa Eva F, "The internet subculture of Indonesian face-veiled women," Int. J. Cult. Stud., vol. 0, no. 0, pp. 1-15, 2013.

[9] "https://www.republika.co.id/." .

[10] Muhtador. M, "Studi Kritis atasTransmisi dan Otoritas Keagamaan di Media Sosial," Fikr. J. Ilmu Aqidah dan Stud. Keagamaan, vol. 6, no. 3, pp. 323-340, 2018.

[11] M.I.Defleur and S.Bell Roekch dalam S. Silvia Fardila, "Tingkat Ketergantungan Pengguna Media Sosial dan Kecemasan Sosial,” J. Interak., vol. 4, no. 1, pp. 1-10, 2015.

[12] L. Straubhaar, J., LaRose, R., and Davenpo, Media Now: Understanding Media, Culture, and Technology, 7th ed. United States of America: Wadsworth, Cengage Learning.

[13] Piela.A., "Online Islamic Spaces as Communities of Practice for Female Muslim Converts Who Wear the Niqab," J. ofWomen Middle East Islam. World, vol. 13, pp. 363-382, 2015.

[14] A. Piela, "How Do Muslim Women Who Wear The Niqab Interact With Others Online? A Case Study Of a Profile ona Photo-Sharing Website," New Media Soc., vol. 19, no. 1, pp. 67-80, 2017.

[15] A. Nurul, "Pakaian Syar'i, Media, dan Konstruksi Kesalehan Perempuan," Sosiol. Reflektif, vol. 13, no. 1, pp. 51-63, 2018.

[16] Fathonah K.Daud, "Trend Jilbab Syar'i Dan Polemik Cadar; Mencermati Geliat Keislaman Kontemporer Indonesia," in Proceeding 2nd Annual Conference For Muslim Scholars UIN Surabaya, 2018.

[17] Sugiyono, Metodologi Penelitian Kuantitatif, Kualitatif Dan R\&D. Bandung: Bandung: Alfabeta, 2013.

[18] Paul K, "Stakeholder Theory, Meet Communications Theory: MediaSystems Dependency and Community Infrastructure Theory, with an Application to California's Cannabis/Marijuana Industry."

[19] Hatta.M., "Sumber Keberagamaan Alternatif Remaja (Fenomena Cyberreligion Siswa SMA Negeri 6 Depok Jawa Barat," Thesis, 2018.

[20] Kemenpppa BPS, "Statistik Gender Tematik: Profil Generasi Milenial Indonesia, Kementerian Pemberdayaan Perempuan dan Perlindungan Anak,” p. 17, 2018.

[21] Hamidah K, "Ngaji Medsos Jihad Digital Generasi Millennial: Merebut Ruang Publik dengan Konten Positif." .

[22] Oktisia P, "Efektivitas Google Talk dalam Meningkatkan Efisiensi Kerja Karyawan Ban Kaltim Cabang Syariah Samarinda," eJurnal Ilmu Komun., vol. 2, no. 1, pp. 321333, 2014.

[23] R. Gómez, G. Braña, and Varela, "Internet Addiction and Its Relationship to Chronotype and Personality in a Turkish University Student Sample," Soc. Sci. Comput. Rev., vol. 32, no. 4, pp. 484-495, 2014, doi: doi:10.1177/0894439313511055.

[24] R. L. Sativa, "https://inet.detik.com."

[25] Krisnawati E, "Perilaku Konsumen di Kalangan Remaja dalam Pencarian Informasi," J. Ilm. Komun., vol. 5, no. 1, 2016.

[26] I. N. R. Ajeng, "Buletin Psikologi," vol. 26, no. 1, pp. 64 - 70, doi: DOI: 
10.22146/buletinpsikologi.31164 ISSN 2528-5858 (Online).

[27] Nurina Hakim dan Aliffatullah Alyu Raj, Dampak Kecanduan Internet (Internet Addiction) Pada Remaja. .

[28] S Silvia F, "Tingkat Ketergantungan Penggunaan MediaSosial dan KecemasanIntereaksi,” J. Ilmu Komun., vol. 4, no. 1, pp. 1-10, 2015.

[29] F. dan W. D. H. P. S. Young, "Pengujian Validitas Konstruk Kriteria Kecanduan Internet," J. Psikol. Vol., vol. 32, no. 2, pp. 74-91, 2005.

[30] L. Smahel, D., Brown, B. B., \& Blinka, "Associations between Online Friendship and Internet Addiction among Adolescents and Emerging Adults," Dev. Psychol., vol. 48, no. 2, pp. 381-288, 2012. 